\title{
THE RIGHT TO KNOW ONE'S ORIGINS IN LIGHT OF THE LEGAL REGULATIONS OF ADOPTION IN SLOVENIA
}

\author{
Suzana KRALJIĆ ${ }^{1}$
}

The relationship between parents and children forms a central part of family law. As a rule, the legal relationship between children and parents also has a coherent biological starting point. However, a legal relationship between parents can also arise through adoption, where legal and biological relationships diverge. Children who have been adopted often want to know the identity of their biological parents. In the past, priority was given to the biological parents' anonymity, but the child's right to know their origin is now at the forefront. Slovenia has implemented new family law legislation; however, it does not specifically address this subject. Adoption court proceedings are not uniform because of this inconsistency. Comparative law, however, provides varied approaches to exercising a child's right to know their origins or biological parents, which is now widely regarded as a critical part of one's identity. The author of the paper analyzes Slovenia's current legal regulations and compares it to contemporary ECtHR case law that has provided the groundwork for modern approaches to the legal regulation of a child's right to know their origin. In this article, the author also attempts to formulate proposals for changes to Slovenia's existing legislation, as well as proposals for de lege ferenda improvements, which, on the one hand, would bring Slovenia closer to realizing children's rights, and, on the other hand, could lead to a unification of Slovenian court case law, ensuring greater legal certainty and predictability.

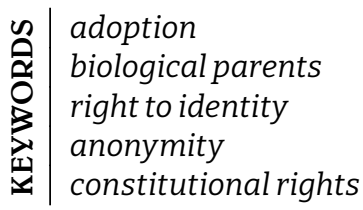

1 | Associate Professor, Faculty of Law, University of Maribor, Slovenia, suzana.kraljic@um.si, ORCID: 0000-0002-4438-6457. 


\section{Introduction}

Knowing one's origin is a given for most people who know their biological parents. ${ }^{2}$ However, some children and adults do not know their biological parents. Putting aside the sociological aspects of children's desire and need to know their biological parents and focusing on the legal background, we can accept that the rapid development of biotechnology has opened up many legally sensitive family law issues. ${ }^{3}$ For a variety of reasons, children search for their biological parents. Not knowing their biological parents is often the missing part in their lives. Knowing own biological parents has also an important role in defining one's identity. Today, we can no longer merely speak of a child's right to know their origin, but of everyone's rights to know their origins. The right to know one's origins has already been enshrined in the constitutions of some countries.

There may be conflicts between the right of the child to know their origins and the parent's right to remain anonymous. Parents who have given up a child for adoption may not want the child to know their identity. The right of children to know their origins has gained importance in recent years, both abroad and in the Republic of Slovenia, which, after more than forty years, has recently adopted a new Family Code (FC). ${ }^{4}$ This article presents the differing approaches to this issue between Slovenia and other countries. The European Court of Human Rights (ECtHR) case law has also set important milestones in this area of children's rights. The right of the child to know their origins will only be analyzed in the context of adoption; it will not be applied to other relationships that are also linked to this right (e.g., in the case of children conceived through artificial insemination, anonymous births, or surrogacy).

\section{Children's rights to know their origins}

The Convention on the Rights of the Child $(C R C)^{5}$ was adopted in 1989. Children's rights have taken on new dimensions and have become an indispensable basis for decisionmaking in all matters concerning children. The CRC is an international human rights treaty that defines children's civil, political, economic, social, health, and cultural rights. The principle of the child's best interests, which is now a fundamental principle of children's law, must be applied to all articles of the CRC. ${ }^{6}$ Children's rights are an area in which the law and the children's daily lives are intertwined.

According to Article 7 of the $\mathrm{CRC}$, children have the right to know and be cared for by their parents. States parties shall ensure the implementation of this right in accordance with their national law and their obligations under the relevant international instruments in this field. However, according to Article 7(1) of the CRC, the child has this right only in so far as it is possible. The provision of Article 7 of the CRC does not therefore impose an obligation on states to guarantee the child the absolute right to know the identity of their

2 | Besson, 2007, p. 138

3 | Lamçe and Çuni, 2013, p. 605.

4 | Uradni list RS, št. 15/17, 21/18 - ZNOrg, 22/19, 67/19 - ZMatR-C, 200/20 - ZOOMTVI.

5 | Uradni list SFRJ, št. 15/90; Uradni list RS, št. 35/92.

6 | Čujovič IN: Novak, 2019, p. 59. 
parents. The CRC leaves it to the States Parties to decide how the state will regulate the rights of the child. ${ }^{7}$ At the same time, it should be stressed that an absolute prohibition of the right to know one's biological parents is contrary to that of the CRC. ${ }^{8}$

Article 8 of the CRC complements Article 7. It sets the right of the child to preserve their own identity, which the CRC does not clearly define. However, the CRC gives three examples of what 'own identity' includes, namely nationality, name, and family relationships (Article $8(1)$ of the CRC). It follows that nationality, name, and family relationships are crucial in defining a child's identity, but are not the only significant information. Article 8(2) of the CRC imposes an obligation on states parties to ensure that, where a child has been illegally deprived of some or all of the elements of their identity, they shall be provided with appropriate assistance and protection in order to re-establish their identity as soon as possible. ${ }^{9}$

The family relationships referred to in Article 8 of the CRC, as an elementary part of the child's right to know their identity, also form the basis for knowledge of parents, both legal/social parents, and biological or gestational ones. The latter has become particularly important in recent years, as many children who have been adopted, born through artificial insemination, or an anonymous birth tend to search for their biological parents. While such a search has been based mainly on paper documents and personal testimonies, the rapid development of modern technologies has further contributed to, and indeed made it possible for children who are now adults to find their biological parents.

Article 1 of the CRC states that for the purposes of the CRC, 'child' refers to every human being below the age of eighteen years unless the law applicable to the child provides that the age of majority is attained earlier. However, a person's search for their own origin and identity usually does not begin until after attaining the age of the majority. This was confirmed by the ECtHR in the case of Jäggi v. Switzerland, in which the ECtHR explicitly pointed out that a person's interest in knowing the identity of their parents does not disappear with age..$^{10} \mathrm{~A}$ child informed during their childhood that they are adopted often does not set out to find their biological parents until they reach the age of majority.

In 2002, the UN Committee on the Rights of the Child explicitly appealed to States Parties to ensure that all States Parties shall take the necessary measures to enable all children, regardless of the circumstances of birth, and adopted children, to obtain information about their parents' identity to the extent possible. ${ }^{11}$ However, the CRC itself does not provide any guidance or conditions for providing this right to children.

\section{Legal regulations of adoption in Slovenia and the right to know one's origins}

\subsection{General}

Although the right to know one's origins is enshrined in the CRC and is thus a fundamental right of a child, it is not enshrined in the Constitution of the Republic of Slovenia

7 | Novak IN: Novak, 2019, p. 742.

8| Ziemele, 2007, p. 27.

9 | See also Clark, 2012, p. 627.

10 | Jäggi v. Switzerland, app. no. 58757/00, 13 February 2006.

11 | Concluding Observations, recommendations 31 and 32, CRC/C/15/Add.188, 8. 
(CRS). ${ }^{12}$ However, the right of a child to know their origins is explicitly provided for in, for example, the constitutions of Serbia ${ }^{13}$ (see Article 64(2)), Uganda ${ }^{14}$ (see Article 34(1)), Namibia $^{15}$ (see Article 15(1)), Malawi ${ }^{16}$ (see Article 23(2)), Costa Rica ${ }^{17}$ (see Article $53^{18}$ ), and the Congo $^{19}$ (see Article 41).

The new FC, adopted in 2017 and entered into force in April 2019, does not include any provision explicitly referring to the right of the child to know their origins. Neither the CRS nor the FC mentions this right. However, this right cannot be denied, given that its legal basis is derived from the CRC. Article 8 of the CRS states that ratified and published international treaties (including CRC) are directly applicable. In 2007, the Constitutional Court of the Republic of Slovenia (CCRS) took a clear position that the right of an individual to know their origin belongs to the set of personality rights. Articles 34 and 35 of the CRS laid down the basis and limits of the constitutional protection of personality rights. Human personality is a combination of several personal goods that are protected by individual personality rights that belong to the human person. The guarantee of personality rights guarantees that the component of an individual's personality that are not protected by other provisions of the CRS, but only together with them, is given the ability to develop freely and shape their life in accordance with their own choices. Among the component that are decisive for the development of an individual's personality is the knowledge of one's origins, that is, the knowledge of one's biological parents. This is one of the components that is crucial to a person's self-conception and the conception of their place in society. Knowing one's origins also has an important impact on family and kinship ties. Not being able to establish one's origins can be a burden and a source of uncertainty for an individual. Therefore, the right to know one's origin is also a part of personality rights. In a broader sense, this is the right to personal identity, which includes the right to a personal name and the right to nationality, and the right to know the identity of one's parents. ${ }^{20}$

The reasons an individual may have for wanting to discover their origins are manifold. They may be rooted in an individual's psychological need for identity. They may also have a medical basis (e.g., knowledge of hereditary diseases) or even reflect the individual's material interests (e.g., inheritance, alimony). A child's research into their origins as an adult may lead to unpleasant consequences for the personal and family lives of all persons involved. However, a child's interest in knowing their origins should outweigh the interests of legal certainty and the need to safeguard the permanence of existing family law relationships. ${ }^{21}$

12 | Uradni list RS, št. 33/91-I, 42/97 - UZS68, 66/00 - UZ80, 24/03 - UZ3a, 47, 68, 69/04 - UZ14, 69/04 - UZ43, 69/04 - UZ50, 68/06 - UZ121, 140, 143, 47/13 - UZ148, 47/13 - UZ90, 97, 99, 75/16 UZ70a, 92/21 - UZ62a.

13 | Službeni glasnik RS, br. 98/06.

14 | See Parliament of the Republic of Uganda, 2021.

15 | Constitute, 2021d.

16 | Constitute, 2021c.

17 | Constitute, 2021b.

18| Unlike other constitutions, Costa Rica's Constitution does not focus only on children, but recognises this right for all.

19 | Constitute, 2021a.

20 | Decision of the Constitutional Court of the Republic of Slovenia U-I-328/05-12,18 October 2007, par. 8.

21 | Decision of the Constitutional Court of the Republic of Slovenia št. U-I-328/05-12, 18 October 2007. 


\subsection{Adoption}

Following Besson, the right to know one's origins amounts to the right to know one's parentage, that is, one's biological family and ascendance, and one's conditions of birth. It protects each individual's interest in identifying where they come from. ${ }^{22}$ It was in the case of adoption, which is an old legal institution that has evolved throughout history and has been adapted to the needs of a particular period, that the question of the right to know one's origins first arose. Today, adoption is the best-known form of social parenthood ${ }^{23}$, where a child is left without parents or cannot be cared for by them. Social parenting is used because both parents, or at least one of them, are not genetically related to the child in adoption. ${ }^{24} \mathrm{~A}$ legal bond between the adoptive parent and the adopted child is established to imitate the natural parent-child relationship. The adoptive parent acquires parental care and the rights and obligations arising therefrom. ${ }^{25}$

For children or people who have been adopted, the knowledge that they have been adopted raises many questions (e.g., who are my biological parents?; why I was given up for adoption?; do I have other relatives?) and a desire to meet their biological parents. This is especially the case in international adoptions, as these children often differ physically from their adoptive parents and thus question their origins. They often not only seek information about their biological parents, but also information regarding their cultural heritage. ${ }^{26}$ Knowing one's biological parents is also important from a medical perspective (e.g., prevention, detection, and treatment of hereditary diseases). This could also be achieved simply by providing data in an anonymized manner. ${ }^{27}$

The right to know one's origin is a fundamental right of the child, but not the adoptive parent. It must be assumed that a woman who has chosen to give her child up for adoption at birth may not want her identity to be known. Similarly, prospective adoptive parents usually do not want biological parents to know who has adopted their child. They may fear that the biological parents can cause problems by tracing their child. This is especially the case if the adoption has resulted from the deprivation of parental care by the biological parents. It follows from the fact that adoption, as an institution of family law, is often intertwined with strong emotions.

Under Slovenian law, the final adoption order also marks an important turning point with regard to the information relating to all three parties involved-the child being adopted, the child's biological parents, and the adoptive parents. Once the adoption order has become final, the adopted person has no right to obtain the personal data of their biological parents, which are kept in the civil registry and other personal data registers. The biological parents who have given the child up for adoption also do not have the right to access the personal data of the child (Article 222(2) FC).

The Slovenian civil register is a computerized database in which adoptions are registered (Article 2(1) of the Civil Register $\mathrm{Act}^{28}$ (CRA)), that is, the adoptive parents are registered as the child's parents. When accessing or extracting data from civil registers,

22 | Besson, 2007, p. 140.

23 In the case of an anonymous birth, a child conceived with donated gamets, or surrogacy, social parenting can also be considered.

24 | Zaviršek, 2012, p. 26.

25 | Kraljić, 2019, p. 788.

26 | Inštitut za socialno politiko RS, 2019.

27 | Fenton-Glynn, 2014, p. 191.

28 | Uradni list RS, št. 11/11 - UPB, 67/19. 
only the names of the adoptive parents, and not the biological parents, are visible (comp. Article 222(1) FC and Article 29(2) of the Rules on the Implementation of the Civil Register Act $^{29}$ (Rules)). This is because in the case of adoption, the birth registration certificate is issued without endorsement of the adoption (Article 29(3) Rules). Information about the adoption from the civil register may be obtained only with the written consent of the person to whom it relates. A child who has attained the age of 15 may give consent if they are capable of understanding its meaning and consequences. Otherwise, the child's legal representative, that is, the adoptive parents or guardian, may give consent. Consent can be obtained by the social work center at the initiative of the adoptee or biological parents. This makes it clear that the task or power of obtaining consent is entrusted to Slovenian social work centers (Article 222(2) FC). Simultaneously, this ensures that the information or circumstances surrounding an adoption are protected from the general public, which cannot freely access the information in the civil registry. ${ }^{30}$

Information about an adopted person's biological parents may relate to:

a) Non-identifying information, including their general appearance, religion, ethnicity, race, education, occupation, etc. This includes the name of the agency (e.g., in the United States) that arranged the adoption, and the facts and circumstances relating to the nature and cause of the adoption.

b) Identifying information about the biological parents or other members of the biological family, consisting of their names and addresses;

c) The medical and psychological data of the biological parents, which may be provided to the registry at any time after adoption. This information is important for adoptive parents, as it can indicate whether a child is at an increased risk for certain diseases. ${ }^{31}$ Ensuring access to health data is also crucial for the enjoyment of the child's right to the highest attainable standard of health under Article 24 of the CRC, as this inevitably also includes information on family history. Denying adequate medical information about children could be detrimental to their standard of care and unnecessarily jeopardize their health. ${ }^{32}$

The Slovenian FC has been very restrictive in terms of providing information that would enable a child to exercise their right to know their origin or knowledge regarding their biological parents. Slovenia is one of the most restrictive countries in this respect, as it makes this right conditional on the consent of the child's biological parents. Many European countries regulate children's right to know the identity of their biological parents. Differences exist as to the age at which the child acquires this right:

a) 12 years: Belgium, Finland, Czech Republic ${ }^{33}$;

b) 14 years: Austria, Hungary, United Kingdom (the exception is Scotland for 14 years);

c) 16 years: Bulgaria, Germany, the Netherlands ${ }^{34}$;

29 | Uradni list RS, št. 40/05, 69/09, 77/16, 102/20.

30 | Farnós Amorós, 2015: p. 7.

31 | Law Offices Stimmel, Stimmel \& Roses, no date.

32 | Childs Rights International Network, 2018.

33 | Children in the Czech Republic have access to adoption information starting at the age of 12. If the original mother of the child requests secrecy of this information at the time of birth, an exception is made. In the case of a 'secret birth', 'anonymous birth', or 'confidential birth', the latter is given. The identity of the mother will only be revealed in these circumstances if a court order will be obtained.

34 I In the Netherlands, the age limit in the case of inter-country adoption is at 12 years. 
d) 18 years: Cyprus, Croatia, Denmark, Estonia, Greece, Lithuania, Latvia, Malta, Poland, Portugal, Romania, Spain, and Sweden.

e) maturity of the child: France, Slovakia;

f) 25 years: Italy;

g) Ireland does not guarantee the right of a child to know their biological parents. Slovenia allows it, but makes it conditional on the consent of the biological parents. ${ }^{35}$

The review shows that most countries have a better approach to the issue than Slovenia. They prioritize the child and their right to know their origins. Although it is also possible under the Slovenian FC for a child to know who their parents are, this is conditional on the consent of the biological parents. If they refuse to give consent, the disclosure of information about the biological parents to the child will not take place. In particular, this will deny the child's psychological need to know their biological parents' identity. Apart from the psychological interest, the child may also have a medical interest, which is realized through Article 222(3) FC, or a material interest (e.g., inheritance), which should not play a primary role in establishing the identity of the biological parents. ${ }^{36}$

An exception to the regulation under Article 222(2) FC is the acquisition of health data. The adoptee or their legal representative may request information from the social work center about the health of the biological parents to the extent and under the conditions provided for by law. ${ }^{37}$ In this case, the social work center will obtain information from health institutions (e.g., possible hereditary diseases) and send it in an anonymized form to the adopted person or their legal representative (Article 222(3) FC). The anonymization of data means that the form of personal data has been changed in such a way that it can no longer be linked to the individual or can be linked only with disproportionate effort, cost, or time. However, when the child has been adopted by the spouse or cohabitation partner of a parent ${ }^{38}$, the provisions of Article 222(2-3) of the FC do not apply, as the child still has one parent.

Social work centers are also responsible for keeping records on children who have been adopted. The latter is not explicitly provided for, but is self-evident, given that the social work center is the body that verifies the suitability of a child for adoption. If the social work center establishes that the child meets the conditions for adoption, it registers the child in the central database of children in need of adoption (Article 218(5) FC). In order for the social work center to reach such a conclusion, it will need to have the relevant documents (e.g., on health and parental consent) at its disposal and to keep them. ${ }^{39}$

35 | FRA, no date.

36 | Povzeto po Končina Peternel, 1998, p. 65.

37 | In In re Adoption of S.J.D. (641 N.W.2d 794 (Iowa 2002)), the court refused to open adoption records for an adopted person even though she was manic depressive. The court held that there was no 'good reason' to justify opening the adoption file. It is clear from US case law that 'good reason' is the legal standard. The court must determine in each individual case whether there are good reasons justifying the opening of the adoption files. Medical reasons are certainly good reasons, but not all of them. Thus, the court did not define the mere existence of manic depression as a good reason, whereas the need for an organ transplant was considered as a good reason justifying the opening of adoption files. Through the practice of the American courts, the view has also emerged that adoption records should be opened if it is necessary to save life or prevent irreparable harm to physical or mental health - see Tilly, 2005; Oliphant \& Ver Steegh, 2016, p. 492.

38 It should be stressed that in Slovenia the same-sex partners living in registred or not registred civil union do not have the right to joint adoption.

39 | Kraljić, 2019, pp. 790-791. 
The conflict of interests between the child and their right to know their origins as an adopted child, and the birth mother's right to remain anonymous was also addressed by the ECtHR in the case of Godelli $v$ Italy. ${ }^{40}$ The ECtHR upheld a violation of Article 8 of the ECHR as the Italian authorities failed to ensure a balance between the child's interest in knowing their origins and the birth mother's right to remain anonymous. In fact, priority was given to the mother, as Italian law allowed women to give birth anonymously in order to prevent unlawful terminations of pregnancy, discarding the child in unsafe circumstances, and ensuring adequate medical care during childbirth. However, the child was not allowed to request information about their ancestors or, with the consent of the biological mother, to reveal her identity. Nor did Italian law provide for a procedure whereby the mother could revoke her request for anonymity. ${ }^{41}$

However, the mere fulfilment of the objective presumption is not sufficient, because the child must also fulfil a subjective presumption, which is manifested in their capacity to understand the meaning and consequences of the given consent. If the objective condition is met, but not the subjective condition, the child's legal representative will be able to give consent. If the child's biological parents do not give consent, the child is prevented from obtaining their information. Biological parents are thus guaranteed anonymity if they do not want their information to be disclosed. Thus, if consent is refused, they will not be able to know the identity of their biological parents. For the child's right to information or knowledge of origin to be realized, three cumulative conditions must be met: i) the child must be at least fifteen years old (objective condition); ii) the child must be able to understand the meaning and consequences of the consent given; and iii) the biological parent must have given their consent. Indeed, a complete denial of the possibility of accessing information on biological parents would be contrary to Articles 7 and 8 . However, the child's right to know who their biological parents are is still not sufficiently protected, as there is no legal obligation under the FC for the adoptive parent to inform the child of their parentage (e.g., in Croatia). ${ }^{42}$ Following the example of other countries, it would also be advisable to shift the scales in this area to the side of the child, ensuring respect for their right to know their biological parents.

What about information revealed during the adoption process itself? Adoption proceedings can only be initiated on the proposal of a social work center (Article 121(1) of the Non-Contentious Civil Procedure Act ${ }^{43}$ (NCCPA-1)). The jurisdiction for adoption is today given to the courts, which decide on them in a non-contentious civil procedure. There is no consensus among social work centers regarding how to proceed in this situation. The social work centers submit proposals in three different copies: i) one for the court, ii) one for the biological parents, and iii) one for the prospective adoptive parents. The court copy of the application contains all the information. The biological parents' copy conceals the information of the prospective adoptive parents, and the adoptive parents' copy conceals the information of the biological parents. The social work centers thus expect the court to conduct the adoption procedure anonymously, although the current arrangements do

40 | Godelli v. Italy, app. no. 33783/09, 25 September 2012.

41 | Velkavrh, 2012, p. 34.

42 | Vučković Šahović \& Petrušić, 2016, p. 109.

43 | Uradni list RS, št. 16/19. 
not support this. ${ }^{44}$ This was also the practice of social work centers before the FC, under the Marriage and Family Relations Act of $1976 .{ }^{45}$

According to Article NCCPA-1, which refers to the right to be heard, the court must give the parties to the proceedings the opportunity to be heard on the allegations made by the other parties, to participate in the taking of evidence, and to discuss the outcome of the proceedings as a whole (Article 5(1) NCCPA-1). As the social work center is the initiator of the adoption procedure in the case of joint adoption, it is an open question as to who the participants are in the adoption procedure. According to Article 21 NCCPA-1, the participants to a non-contentious civil proceedings are: i) the initiator (applicant) of the proceedings; ii) the persons against whom the proposal is filed (the counterparty); iii) the person with respect to whom the proceedings are brought (the child to be adopted); iv) or the person who will be directly affected by the court's decision (the prospective adoptive parent and the biological parents); v) and the person whose legal interest may be affected by the court's decision. Participants may also be persons and authorities entitled by law to take part in the proceedings. It follows from the foregoing that the prospective adoptive parents, the biological parents, and the child also have the status of a participant in the adoption proceedings (with the exception of the social work center as the petitioner). In non-contentious procedures, including adoption proceedings, the court must respect the right to be heard by all participants.

The court may also make a decision without giving the participant an opportunity to be heard if the law so provides or if the court considers that this would jeopardize the other constitutional rights of a person whose rights and legal interests the court is obliged to protect ex officio (Article 5(2) of the NCCPA-1). ${ }^{46}$ Given that adoption is a special form of child protection, the court must protect the rights and legal interests of the child. However, the constitutional rights of the child in adoption proceedings are in no way jeopardized in such a way as to justify depriving the other participants in the adoption proceedings of their right to be heard on the allegations made by the other participants, to participate in the taking of evidence, and to discuss the outcome of the proceedings as a whole. ${ }^{47}$

Since the new Slovenian FC came into force, diverse perspectives on the protection of data on children's biological parents and prospective adoptive parents have evolved. Before the social work center files a petition with the court, the biological parents are made aware of the information about the potential adoptive parents, as they must consent to the child's adoption. According to the legal act, consent to adoption cannot be given to a person whose complete name is not specified because the FC is unaware of the incognito or blanco adoption. ${ }^{48}$ As a result, the concealing of the prospective adoptive parent's personal information in the adoption petition itself is useless or needless, because the biological parents are already aware of it. ${ }^{49}$ The adopted parents' names and surnames are

44 | Horvat-Pogorelec, 2021, pp. 6-8.

45 | Uradni list RS, št. 69/04 - UPB, 101/07 - odl. US, 90/11 - odl. US, 84/12 - odl. US, 82/15 - odl. US, $15 / 17$ - DZ, 30/18 - ZSVI.

46 | Rijavec IN: Rijavec 8 Galič, 2020: pp. 50-51.

47 | Horvat-Pogorelec, 2021, pp. 6-8.

48 | Biological parents consent to an adoption in a 'blanco adoption' without knowing who would adopt their child. The adoptive parents are already known in an 'incognito adoption', but only to the authority that will carry out the adoption, not to the biological parents who consent to have their kid adopted (Kraljić, 2019, p. 731; Novak, IN: Novak, 2019, p. 743).

49 | Horvat-Pogorelec, 2021, pp. 6-8. 
listed in the adoption decision. As previously indicated, under the new Slovenian FC, until the adoption decision is final, the adoptee has no right to know their biological parents' personal data, which is registered in the civil registry and other personal data registries. The biological parents of a child who has been placed for adoption do not have the right to access the child's personal information (Article 222(3) FC).

Article 22 of the European Convention on the Adoption of Children (ECAC) also deals with access to and disclosure of information. ${ }^{50}$ The ECAC prioritizes the disclosure of identity, that is, open adoption. However, it may be decided that adoption will take place without disclosing the identity of the adoptive parent to the child's biological family (Article 22(1) ECAC), that is, a closed adoption. The ECAC guarantees the adopted child access to information held by the competent authorities about their origin (Article 22(3) ECAC). If the biological parents of an adopted child have a legal right not to disclose their identity, the competent authority has the right to determine whether to overrule this right and disclose information about their identity, to the extent permitted by law. In doing so, the authority must consider the circumstances of the case and the rights of the child and their biological parents. The right of an adopted child to know their origin is not an absolute right under the ECAC. It is also impossible to prohibit this right completely. In all circumstances, a balance must be achieved between the child's right to know their origins and the biological parents' right to remain anonymous. ${ }^{51}$

An adopted child who has not yet reached the age of the majority may be given appropriate counselling (Article 22(3) ECAC). The adoptive parent and the adopted child must be able to obtain a document containing extracts from public records confirming the adopted child's date and place of birth. It is not necessary to reveal the fact of adoption or the identity of the biological parents (Article 22(4) ECAC). Taking into account the right of a person to know the identity and origin of an adopted child, under Article 22(5) ECAC, information on the adoption shall be collected and kept for at least fifty years after the finality of the adoption, as adoptees often wish to have access to that information in adulthood. ${ }^{52}$ However, civil status registers should be maintained in such a way that only those persons who demonstrate a legitimate interest in the information recorded in them will be granted access. Persons who do not have such an interest should be denied or prevented from obtaining such information (Article 22(6) ECAC). The current Slovenian regulation on access to biological parents' information differs from ECAC's Article 22(3) (see above). However, this cannot be interpreted as a reason Slovenia should not ratify the ECAC. Upon accession to information, Slovenia could make reservations to Article 22(3) of the ECAC.

Sweden has also not acceded to the ECAC because, unlike the ECAC, under Swedish law, adult children who have been adopted have an absolute right to disclose the identity of their biological parents. This is because the child's right to know their origin always overrides the parents' right to anonymity. ${ }^{53}$

50 | The European Convention on the Adoption of Children (Revised) was opened for signature in Strasbourg on 27 November 2008 and became applicable on 1 September 2011. Only ten countries have ratified the ECAC (as of 10 September 2021), namely Belgium, Germany, Denmark, Malta, Finland, Norway, Ukraine, Romania, the Netherlands, Spain. Slovenia has not acceded to the ECAC. 51 | Council of Europe, 2008, p 11.

$52 \mid$ Council of Europe, 2008, p. 11.

53 | Center for Adoption Policy, no date; see tudi Kovaček Stanić, 1997, p. 172. 
In the case of Odièvre v. France ${ }^{54}$, the ECtHR ${ }^{55}$ considered an adopted child's right to know about their origins. The ECtHR acknowledged that people have a fundamental right to know their origins, but also found that the mother had a legitimate interest in remaining anonymous. At the same time, it emphasized that the right to information about one's origins and the identity of one's biological parents is an essential element of an individual's personality. The ECtHR found that France had not violated Article 8 of the European Convention on Human Rights (ECHR), as it had succeeded in ensuring a fair balance between the competing interests (the mother's right to remain anonymous and the child's right to know their origins). ${ }^{56}$ The ECtHR case in question concerned an adult complainant who was adopted at the age of four. The complainant's mother requested anonymity at birth under the French system ('accouchement sous $X^{\prime 57}$ ). In this case, the ECtHR assessed the French anonymous birth regime. Although the mother has the right to remain anonymous, she can waive this right at a later time, so that the child can learn her identity and have access to non-identifiable information about her. ${ }^{58}$ Even if the biological parent does not consent to the disclosure of their identity, the competent authority must be able to authorize disclosure in situations in which the circumstances are reasonable..$^{59}$

\section{Conclusion}

The right of a child to know their origin is now recognized in a number of international documents (such as CRC and ECAC) as well as in numerous national laws. However, differences remain between national law and international documents. Some countries deny the child's right to know their origin (e.g., Ireland), and there are disparities regarding the age at which a child can exercise this right among those that explicitly recognize the child's rights (e.g., 14, 15, 16, 18 years). ${ }^{60} \mathrm{~A}$ further distinction is made regarding whether countries recognize it as an absolute right of the child, that is, a right that always prevails over the biological parents' right to anonymity (e.g., Sweden), or as a non-absolute right, in which proportionality must be considered according to the circumstances of the case, as well as the right of the child to know their origins and the right of the biological mother to remain anonymous.

Another distinction is that certain countries require adoptive parents to inform the adopted child of their adoption. Article 92 of the Federation of Bosnia and Herzegovina's Family Act expressly stipulates that a child has the right to know the identity of their parents. Adoptive parents are even required by law to inform the adopted child about the adoption no later than the child's seventh birthday, or immediately after the adoption if

54 | Odièvre v. Franciji, app. no. 42326/98, 13 February 2003.

55 | Already in 2002, in case Mikulić v. Croatia (app. no. 53176/99, 7 February 2002), the ECtHR stressed that it is crucial for an individual to know their biological father, as knowledge of one's origins is an important element in the formation of an individual's personality.

56 | Council of Europe, 2019, p. 55.

57 | Več glej Besson, 207: p. 139; Clark, 2012, p. 634.

58 | Odièvre proti Franciji, app. no. 42326/98,13. februar 2003.

59 | Velkavrh, 2012, p. 34.

60 | FRA, no date. 
the adopted child is older ${ }^{61}$ Croatia has a similar law. Adoption is a highly compassionate relationship, and it would be ethically and morally unacceptable to construct this relationship based on a misunderstanding of one's origins. ${ }^{62}$ However, it is also crucial to guarantee that adoptive parents are sufficiently supported in taking the best approach to transmit such important information to the child (e.g., in Slovenia, parents are aided by social work centers).

There is also a fairly consistent arrangement in place to secure the data protection or anonymity of the prospective adoptive parent in relation to the biological parents, and vice versa, during the adoption process. Of course, there are exemptions in the event of so-called open adoptions. However, the Slovenian legal regulations today depart from this. The current procedures show a lack of uniformity and uncertainty. As a result, despite the fact that both laws have only been in effect since April 2019, the Slovenian legal regime, both substantive under the FC and procedural under the NCPPA-1, would need to be revised or supplemented. This will assure compliance with the ECtHR case law and the CRC on the one hand, and more uniform adoption proceedings by Slovene courts, on the other. De lege ferenda, the necessary amendments should be made to allow children to exercise their rights to know their biological parents or origin. The latter is now restricted because of its reliance on biological parents' consent. De lege ferenda regulations should put the child at the forefront. It should also be clarified that the child has the right to know the identity of their biological parents. The adoptive parent should thus be obliged to inform the child of the adoption. This would ensure an improvement in the existing legal regulations and increase the protection of the child's best interests.

61 | Nekatere države ne vežejo to na starost otroka, temveč na otrokovo sposobnost razumeti posledice tovrstnega razkritja.

62 | Bubić \& Traljić, 2007, p. 126. 


\section{Bibliography}

Besson, S. (2007) Enforcing the Child's Right to Know her Origin's: Contrasting Approaches under rhe Convention on the Rights of the Child and the European Convention on Human Rights, International Journal of Law, Policy and the Family, 21(2), pp.137-155.

Bubić, S. and Traljić, N. (2007) Roditeljsko i starateljsko pravo. 1st, Sarajevo: Pravni fakultet Univerziteta u Sarajevu.

Case Godelli v. Italy, app. no. 33783/09, 25 September 2012.

| Case Jäggi v. Switzerland, app. no. 58757/00,13 June 2006.

I Case Mikulić v. Croatia, app. no. 53176/99, 7 February 2002.

| Case Odièvre v. France, št. 42326/98,13 February 2003.

Center for Adoption Policy (no date) Overview od Swedish adoption law [Online]. Available at: http://www.adoptionpolicy.org/pdf/eu-sweden.pdf (Accessed 22 April 2021).

Childs Rights International Network (2018) Article 7: name and nationality [Online]. Available at: https:/archive.crin.org/en/home/rights/convention/articles/article-7name-and-nationality.html (Accessed 5 August 2021).

Civil Register Act (Zakon o matičnem registru - CRA): Uradni list RS, št. 11/11-UPB.

Clark, B. (2012) A balancing act? The rights of donor-conceived children to know their biological origins. Georgia Journal of International and Comparative Law, 40(3), pp. 619-661.

Constitute (2021a) Constitution Congo [Online]. Available at: https://www. constituteproject.org/constitutions?lang=en\&q=right\%20to\%20know\&status=in forceEstatus=is_draft (Accessed 5 September 2021).

Constitute (2021b) Constitution Costa Rica [Online]. Available at: https://www. constituteproject.org/constitutions?lang=en\&q=right\%20to\%20know\&status=in forcefstatus=is_draft (Accessed 5 September 2021).

Constitute (2021c) Constitution Malawi [Online]. Available at: https://www. constituteproject.org/constitutions?lang=en\&q=right\%20to\%20know\&status=in force\&status=is_draft (Accessed 5 September 2021).

Constitute (2021d) Constitution Namibia [Online]. Available at: https://www. constituteproject.org/constitutions?lang=en\&q=right\%20to\%20know\&status=in _ force\&status=is_draft (Accessed 5 September 2021).

Constitution of the Republic of Slovenia (Ustava Republike Slovenije - CRS): Uradni list RS, št. 33/91-I, 42/97 - UZS68, 66/00 - UZ80, 24/03, - UZ3a, 47, 68, 69/04 - UZ14, 69/04 - UZ43, 69/04 - UZ50, 68/06 - UZ121,140,143, 47/13 - UZ148, 47/13 - UZ90,97,99 in 75/16 - UZ70a. 
Convention on the Rights of the Child (Konvencija o otrokovih pravicah - CRC): Uradni list SFRJ, št. 15/90; Uradni list RS, št. 35/92.

Council of Europe (2008) Explanatory Report to the European Convention on the Adoption of Children (Revised) - Strasbourg, 27.XI.2008 [Online]. Available at: https:// rm.coe.int/CoERMPublicCommonSearchServices/DisplayDCTMContent?documentI $\mathrm{d}=09000016800 \mathrm{~d} 3833$ (Accessed 22 April 2021).

Council of Europe (2018) Guide on Article 8 of the European Convention on Human Rights - Right to respect for private and family life, home and correspondence, last updated 30.12.2020 [Online]. Available at: https://www.refworld.org/pdfid/5a016ebe4. pdf (Accessed 5 September 2021).

Decision of the Constitutional Court of the Republic of Slovenia U-I-328/05-12, 18 October 2007.

| European Convention on Human Rights (ECHR): Uradni list RS, št. 33/94, MP, št. 7/94.

European Convention on the Adoption of Children (Revised) [Online]. Available at: https://rm.coe.int/1680084823 (Accessed 10 September 2021).

Family Code (Družinski zakonik - FC): Uradni list RS, št. 15/17, 21/18 - ZNOrg, 22/19, 67/19 - ZMatR-C, 200/20 - ZOOMTVI.

Farnós Amorós, Esther (2015) Donor anonymity, or the right to know one's origins?. Catalan Social Sciences Review, 5: pp. 1-10.

Fenton-Glynn, C. (2014) Children's rights in intercountry adoption: a European perspective. Cambridge: Intersentia.

FRA (no date) Accessing adoption files and information on the biological family [Online]. Available at: https://fra.europa.eu/en/publication/2017/mapping-minimumage-requirements/accessing-adoption-files (Accessed 5 May 2021).

Horvat-Pogorelec, M. (2021) Razkrivanje osebnih podatkov v postopkih posvojitve. Pravna praksa, no. 11, pp. 6-8.

I In re Adoption of S.J.D. (641 N.W.2d 794 (Iowa 2002).

Inštitut za socialno politiko RS (2019) Smernice za delo na področju posvojitev [Online]. Available at: https://www.irssv.si/upload2/Posvojitve_dopolnjeno_koncno_ porocilo_1.4.pdf (Accessed 29 August 2021).

Končina Peternel, M. (1998) Pomoč otrokom, ko starši odpovedo. Ljubljana: Znanstveno in publicistično središče.

| Kovaček Stanić, G. (1997) Pravo deteta da zna svoje poreklo. Novi Sad: Serkl.

| Kraljić, S. (2019) Družinski zakonik s komentarjem. Maribor: Poslovna založba MB.

Lamçe, J. \& Çuni, E. (2013) The Right of the Children to Know Their Origin in Adopting and Medically Assisted Reproduction. Mediterranean Journal of Social Sciences 4(6), pp. 605-610. 
Law Offices Stimmel, Stimmel \& Roses (no date) Adopted Child's Right to Information as to Biological Parents [Online]. Available at: https://www.stimmel-law.com/en/articles/ adopted-childs-right-information-biological-parents (Accessed 21 June 2021).

Marriage and Family Relations Act (Zakon o zakonski zvezi in družinskih razmerjih MFRA): Uradni list RS, št. 69/04 - UPB, 101/07 - odl. US, 90/11 - odl. US, 84/12 - odl. US, 82/15 - odl. US, 15/17 - DZ, 30/18 - ZSVI.

Non-Contentious Civil Procedure Act (Zakon o nepravdnem postopku - NCCPA): Uradni list RS, št. 16/19.

I Novak, B. (ed.) (2019) Komentar Družinskega zakonika. Ljubljana: Uradni list RS.

I Oliphant, R. E. \& Ver Steegh, N. (2016) Family law, $5^{\text {st }}$. New York: Wolters Kluwer.

Parliament of the Republic of Uganda (2021) Constitution [Online]. Available at: https:// www.parliament.go.ug/documents/1240/constitution (Accessed 5 September 2021).

Rijavec, V. \& Galič, A. (eds.) (2020) Zakon o nepravdnem postopku (ZNP-1) - razširjena in uvodna pojasnila. Ljubljana: GV Založba.

Rules on the implementation of the Civil Register Act (Pravilnik o izvrševanju zakona o matičnem registru - Rules): Uradni list RS, št. 40/05, 69/09, 77/16.

Tilly, D. (2005) Confidentiality of Adoption Records in Texas: A Good Case for Defining Good Cause. 57 Baylor L. Rev. 531.

Velkavrh, A. (2012) Posvojeni otrok mora imeti možnost seznanitve s podatki o bioloških starših, Pravna praksa, 39-40, p. 34.

Vučković Šahović, N. \& Petrušić, N. (2016) Prava deteta. $2^{\text {st }}$. Niš: Pravni fakultet Univerziteta u Nišu.

Zaviršek, D. (2021) Notranje in meddržavne posvojitve: od osebnih izkušenj do dobre prakse, Ljubljana: Fakulteta za socialno delo.

Ziemele, I. (2007) Article 7: the right to birth registration, name and nationality and the right to know and be cared for by parents. Leiden: Marrtinus Nijhoff Publishers. 